\title{
BIOCHEMIAL CHARACTERSTICS FOR SNAILS HEMOLYMPH OF Eobania vermiculata AND Monacha cartusiana IN EGYPT
}

\author{
Ghada B.A. Badran $^{1 *}$, Lamiaa M.M. El-Maghraby ${ }^{2}$, S.A.A. El-Massry ${ }^{1}$ and M.A. Doheim ${ }^{2}$ \\ 1. Plant Prot. Res. Inst., Agric. Res. Cent. Dokki, Giza, Egypt \\ 2. Bioch. Dept., Fac. Agric., Zagazig Univ., Egypt
}

Received: 18/04/2017 ; Accepted: 14/05/2017

\begin{abstract}
This study was carried out in Sharkia Governorate, Egypt to compare between biochemical constituents contents, enzymes activities and elements concentrations in shell of two species of most dangerous land snail in Egypt (Monacha cartusiana and Eobania vermiculata). The obtained results showed that $M$. cartusiana hemolymph was charactarizd with high concentration of carbohydrates $(2798.33 \pm 59.18 \mathrm{ug} / \mathrm{ml})$, total lipids $(657.00 \pm 23.28 \mathrm{ug} / \mathrm{ml})$, total protein $(25.05 \pm 0.47$ $\mathrm{mg} / \mathrm{ml})$, malondialdehyde (MDA) $(11.43 \pm 0.33 \mathrm{n} \mathrm{mol} . / \mathrm{ml})$ and urea content $(138.33 \pm 7.04 \mathrm{mg} / 100 \mathrm{ml})$. Also enzymes activities [Alanine aminotransferase (ALT), Aspartate aminotransferase (AST), Glutathione S-transferase (GST) and phenol oxidase)] were higher in the hymolymph of $M$. cartusiana than those in hemolymph of E. vermiculata. Shell contents of elements in E.vermiculata was contained a higher concentration of P (232.14 $\pm 4.04 \mathrm{ppm}), \mathrm{Mg}(566.25 \pm 3.46 \mathrm{ppm})$, Fe (487.82 \pm 6.77 ppm), Cu (18.94 \pm 2.30 ppm), K (1202.50 \pm 4.04 ppm), Na (1230.25 \pm 5.77 ppm) and Zn (5.98 \pm 1.15 $\mathrm{ppm}$ ) than those of $M$. cartusiana, while shell of $M$. cartusiana was characterized with higher content of Ca (503925.00 $\pm 14.43 \mathrm{ppm})$ than shell of E. vermiculata.
\end{abstract}

Key words: Land snails, carbohydrates, protein, lipids, urea, enzymes, elements.

\section{INTRODUCTION}

Land snails are found in most governorates of Egypt as stated by Bishara et al. (1968), ElOkda (1984), Abd El-Aal (2001), Metwally et al. (2002), El-Deeb et al. (2003), Ramzy (2009), Shetaia et al. (2009), Abo-Elnaser (2013), Eshra (2013), Rady et al. (2014) and Abd El-Aleem et al. (2015). Heavy damage to cereal, maize, Egyptian clover, vegetables, potatoes, lettuce, carrots, cabbage, citrus, seed of oil plants, leaves of ornamental plants, peach, palm and bean was caused by snails (Bishara et al., 1968; El-Okda, 1981; Ismail et al., 2003; Lokma, 2007; Shahawy et al, 2008). The damage by snails depends not only on their activity and population density, but also on their feeding habits (Abd El-Aleem et al., 2015). Crops contaminated by snail slime lose their marketability and hence their export potential in many countries as mentioned by (Baker and Hawke, 1990; Ittah and Zisman, 1992).

On the other hand, there are snails, such as Helix pomatial, have high demand and are highly valued in the countries of the European Union, where they are consumed as food products and for medical aims (Zymantiene et al., 2006).

In Sharkia Governorate, Egypt, there are two species of land snails known as brown garden snail, Eobania vermiculata (Muller) and the glassy clover snail, Monacha cartusiana (Montagu). These snails are destructive agricultural pests causing economic damage to a wide variety of plants including horticulture, field crops and vegetables (Abd El-Aal and Hamed, 2010; Abd El-Aleem et al., 2015).

Chemical analysis of land snails dependent on active and aestivation periods, since glucose

\footnotetext{
* Corresponding author: Tel. : +201006045389

E-mail address: ghadabadran@yahoo.com
} 
was decreased in aestivation periods compared with the period of activity (Ismail et al., 2013). Shell are mainly chitin and conchiolin , which consist of protein hardened with calcium carbonate as well with a variety of mineral salts (Lambert, 1973; Bowen, 1996; Etim, 2015). Also, Dominika (2008) found that shells contained $48 \%$ mass $\mathrm{CaCO}_{3}$ mainly in the form of aragonite with small quantities of calcite. There maining $2 \%$ mass were probably compounds of $\mathrm{Fe}, \mathrm{Mg}, \mathrm{Mn}, \mathrm{Al}, \mathrm{Na}, \mathrm{K}$. None of the element exceeded $1 \%$ mass. The concentration of glucose and total protein in the hymolymph of the garden snails Helix pomatia $\mathrm{L}$. were $0.8 \pm 0.12 \mathrm{mmol} / \mathrm{l}$ and $44.18 \pm 13.25 \mathrm{~g} / \mathrm{l}$, respectively (Bislimi et al., 2013). Alanine amino transaminase (ALT) and Aspartate transaminase (AST) activities were determined by (El-Gohary and Genana, 2011) in the two land snails, E. vermiculata and M.cantiana. They

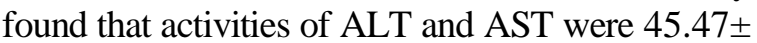
4.32 and $586.33 \pm 16.50$, respectively for E. vermiculata, while they were $221.70 \pm 3.06$ and $923.70 \pm 25.11$, respectively for $M$. cantiana. So this study was conducted to compare biochemical constituents, enzyme activities and shell element concentrations in both land snails Eobania vermiculata (Muller) and Monacha cantiana (Montagu) which are particulary the most common and serious pests in Egypt.

\section{MATERIALS AND METHODS}

This study was carried out at the Agriculture Biochemistry Department, Faculty of Agriculture, Zagazig University and Minestry of Agriculture, Egypt, to compare biochemical constituents, enzyme activities and minerals between two land snail varities, Monacha cartusiana and Eobania vermiculata.

\section{Tested Animals}

Two species of land snails, glassy clover snail, Monacha cartusiana and brown garden snail, Eobania vermiculata which were used in this study and classified according to (Godan, 1983) as follows :

Kingdom: Animalia

Subkingdom: Metazoa

Phylum: Mollusca
Class: Gastropoda

Subclass: Pulmonata

Order: Stylommatophora

Superfamily : Helicidae

Genus: Eobania

Species: Eobania vermiculata

Subfamily: Monacheae

Genus: Monacha

Adult snails of Monacha cartusiana were collected during March 2015 from fields cultivated with Egyptian clover at Alqurien, Abou Hammad Distrect, Sharkia Governorate, Egypt, while adults snails of Eobania vermiculata were collected from orchard fields at Moshtohor village, Toukh Distrect, Kalubia Governorate, Egypt during March, 2015. The collected snails were transferred to the laboratory, and then reared in plastic containers $(40 \times 30 \times 30 \mathrm{~cm})$ with soil base (10 snails/ jar) and fed on lettuce.

\section{Methods}

The present study was conducted to identify the activity of A spartate aminotransferase (AST), alanine aminotransferase (ALT), Glutathione Stransferase (GST), malondialdehyde (MDA), Phenoloxidase, total carbohydrates, total lipids (TL), total proteins (TP) and urea in the haemolymph of adults of Monacha cartusiana and Eobania vermiculata beside identification of element concentration of the shell ( $\mathrm{Ca}, \mathrm{Zn}, \mathrm{Na}$, $\mathrm{K}, \mathrm{Cu}, \mathrm{Fe}, \mathrm{Mg}, \mathrm{P}$ ).

\section{Preparation of snails for biochemical assay}

The snails shell was cleaned with a paper towel and the hemolymph then collected by making a pierce just above the level of the pericardial cavity, and then a fine micropipette inserted carefully through a tiny hole and for aspiration of hemolymph according to (Bezzerra et al., 1997). One $\mathrm{ml}$ of hemolymph was obtained from 30 snails of each two land snails. The collected hemolymph was centrifuged at 3000 (rpm) for 10 minutes in order to precipitate hemocytes and cellular debris. The resulting supernatant was used in the laboratory analyses then the shells of tested snails were removed by making a cut around the whorls in a continuous manner starting at the aperture 
opening using bone scissors and the broken fragments of the shell were carefully removed to determine elements concentration.

\section{Activity of ALT and AST}

The activity of both ALT and AST were determined according to the method of Reitman and Frankle (1957).

\section{GST determination}

Glutathione S-transferase (GST) activity was estimated by the method of Habig et al. (1974).

\section{Lipid peroxidation (MDA) status}

Lipid peroxidation level was determined by using biodiagnostic kit No. MD2529 which is based on the spectrophotometric method of Ohkawa et al. (1979)

\section{Phenoloxidase activity}

Phenoloxidase activity was determined according to the method of Ishaaya (1971).

\section{Determination of total soluble carbohydrate}

Total soluble carbohydrates were extracted and prepared for assay according to Crompton and Birt (1967). Determination was carried out according to Dubios et al. (1956).

\section{Determination of total lipids}

Total lipids were estimated by the method of Knight et al. (1972) .

\section{Total proteins}

Total proteins were determined by the method of Bradford (1976)

\section{Urea determination}

Urea was assayed using BioScope kit (BioScope diagnostics, www.betalab-eg.com) according the method of Young (1990).

\section{Element determination}

Elements in shells of tested snails were estimated by the methods of Perkin-Elmer (1964) and Walsh (1955).

\section{Statistical Analysis}

Statistical analysis was conducted on the data according to (Snedecor, 1951).

\section{RESULTS AND DISCUSSION}

The chemical constituents of land snails hemolymph were determined at active period (March), because concentration of bioconstituents dependant on both active period and aestivation period (Ismail et al., 2015). Also tolerance of land snails against organic or inorganic agents attributed to biochemical constituents (Bislimi et al., 2013).

So results in Table 1 show the values of total soluble carbohydrates (ug/ml), total lipids (ug/ $\mathrm{ml})$, total proteins $(\mathrm{mg} / \mathrm{ml})$, total malondialdyde (MDA, nM/ml) and urea content in hemolymph of two species of land snails (E. vermiculata and $M$. cartusiana). Results of soluble carbohydrates contents in hemolymph of $M$. cartusiana were higher than those of E.vermiculata (2798.33 \pm 59.18 and $2340.00 \pm 40.41 \mathrm{ug} / \mathrm{ml}$, respectively). Also M. cartusiana hemolymph was characterized with higher contents of lipids $(657.00 \pm 23.28 \mathrm{ug} / \mathrm{ml})$, total protein $(25.05 \pm$ $0.47 \mathrm{mg} / \mathrm{ml})$, MDA $(11.43 \pm 0.33 \mathrm{nM} / \mathrm{ml})$ and urea content $(138.33 \pm 7.04 \mathrm{mg} / 100 \mathrm{ml})$, as shown in Table 1, than those of E. vermiculata hemolymph $(476.66 \pm 28.47,21.16 \pm 0.47 \mathrm{mg} / \mathrm{ml}$, $7.80 \pm 0.17$ and $108.66 \pm 5.78 \mathrm{mg} / 100 \mathrm{ml}$, respectively). These trends were conformed with those noticed by Ismail et al. (2013) who mentioned that, at aestivation period these parameters were increased. Table 2 elucidated results responded enzymes activities in hemolymph of M.cartusiana and E.vermiculata, where hemolymph of $M$. cartusiana has a high activities of ALT $\left(130.33 \pm 8.95 \mathrm{u} \mathrm{x} 10^{3} / \mathrm{ml}\right)$, AST $\left(795.00 \pm 17.78 \mathrm{u} \mathrm{x} 10^{3} / \mathrm{ml}\right)$, GST $(13.93 \pm$ $5.19 \mathrm{mMol} . s u b . c o n j u g a t e d / \mathrm{ml})$ and phenol oxidase $\left(1560.66 \pm 27.03\right.$ O.D units $\left.\times 10^{3} / \mathrm{min} / \mathrm{ml}\right)$, while E.vermiculata has a low activities of ALT(65.66 $\left.\pm 3.96 \mathrm{ux} 10^{3} / \mathrm{ml}\right)$, AST $(149.00 \pm 6.08$ $\left.\mathrm{ux} 10^{3} / \mathrm{ml}\right)$, GST $(10.80 \pm 0.30 \mathrm{mMol}$. sub. conjugated $/ \mathrm{ml})$ and phenol oxidase (1104 \pm 58.12 O.D.units $\times 10^{3} / \mathrm{min} / \mathrm{ml}$ ). These results were in agreement with those stated by El-Gohary and Genana (2011) who stated that, E.vermiculata has a lower activities of ALT (45.97 \pm 4.32 $\mathrm{Ux} 10^{3} / \mathrm{mg}$ protein) and AST (586.33 \pm 16.50 $\mathrm{Ux} 10^{3} / \mathrm{mg}$ protein) than those of M.cantiana $\left(221.70 \pm 3.06\right.$ and $923.70 \pm 25.11 \mathrm{U} \mathrm{x} 10^{3} / \mathrm{mg}$ protein, respectively). According to the results in Table 3 it can be noticed that element contents 
Table 1. Amounts of total carbohydrates, total lipids, total proteins, MDA and urea in both land snails hemolymph Eobania vermiculata and Monacha cartusiana in active period

\begin{tabular}{|c|c|c|c|c|c|}
\hline $\begin{array}{l}\text { Parameter } \\
\text { Land snails }\end{array}$ & $\begin{array}{c}\text { Total carbohydrate } \\
\text { (ug/ml) }\end{array}$ & $\begin{array}{c}\text { Total lipids } \\
\text { (ug /ml) }\end{array}$ & $\begin{array}{c}\text { Total proteins } \\
(\mathrm{mg} / \mathrm{ml})\end{array}$ & $\begin{array}{c}\text { MDA } \\
\text { (n mole/ml) }\end{array}$ & $\begin{array}{c}\text { Urea } \\
(\mathrm{mg} \%)\end{array}$ \\
\hline Eobania vermiculata & 2040.00140 .41 & $476.66 \pm 28.47$ & $21.16 \pm 0.47$ & $7.80 \pm 0.17$ & $100.00=$ \\
\hline Monacha cartusiana & $2798.33 \pm 59.18$ & $657.00 \pm 23.28$ & $25.05 \pm 0.47$ & $11.43 \pm 0.33$ & $138.33 \pm 7.04$ \\
\hline
\end{tabular}

Table 2. Enzyme activities of both land snails hemolymph Eobania vermiculata and Monacha cartusiana in active period

\begin{tabular}{|c|c|c|c|c|}
\hline Land snails & $\begin{array}{c}\text { ALT } \\
(\mathrm{UX10} / \mathrm{ml})\end{array}$ & $\begin{array}{c}\text { AST } \\
(\mathrm{UX10} / \mathrm{ml})\end{array}$ & $\begin{array}{c}\text { GST (m mole } \\
\text { sub.conjugated/ml) }\end{array}$ & $\begin{array}{c}\text { Phenol-oxidase } \\
\text { (O.D.unitsx10 } / \mathrm{min} / \mathrm{ml} \text { ) }\end{array}$ \\
\hline ata & 65. & .08 & 30 & 1104 \\
\hline Monacha cartusiana & $130.33 \pm 8.95$ & $795.00 \pm 17.78$ & $13.93 \pm 5.19$ & $1560.66 \pm 27.03$ \\
\hline
\end{tabular}

Table 3. Contents of some elements (ppm) in shell of both land snails Eobania vermiculata and Monacha cartusiana in active period

\begin{tabular}{lcccccccc}
\hline Element & $\mathbf{P}$ & $\mathbf{M g}$ & $\mathbf{F e}$ & $\mathbf{C u}$ & $\mathbf{K}$ & Na & Zn & Ca \\
Land snails & & & & & & & & \\
\hline \multirow{2}{*}{ Eobania vermiculata } & 232.14 & 566.25 & 487.82 & 18.94 & 1202.50 & 1230.25 & 5.98 & 124987.50 \\
& \pm 4.04 & \pm 3.46 & \pm 6.77 & \pm 2.30 & \pm 4.04 & \pm 5.77 & \pm 1.15 & \pm 1.15 \\
\multirow{2}{*}{ Monacha cartusiana } & 197.97 & 267.5 & 100.50 & 16.92 & 1034.25 & 584.75 & 3.61 & 503925.00 \\
& \pm 2.88 & \pm 4.04 & \pm 5.77 & \pm 0.57 & \pm 8.08 & \pm 4.61 & \pm 0.05 & \pm 14.43 \\
\hline
\end{tabular}

in the shell of E.vermiculata characterized with high contents of $\mathrm{P}(232.14 \pm 4.04 \mathrm{ppm}), \mathrm{Mg}$ (566.25 $\pm 3.46 \mathrm{ppm})$, Fe (487.82 $\pm 6.77 \mathrm{ppm}), \mathrm{Cu}$ (18.94 $\pm 2.30 \mathrm{ppm}), \mathrm{K}(1202-50 \pm 4.04)$, Na (1230.25 $\pm 5.77 \mathrm{ppm}), \mathrm{Zn}(5.98 \pm 1.15 \mathrm{ppm})$, but Ca was low content (124987.50 $\pm 1.15 \mathrm{ppm})$ as compared with Ca content in $M$. cartusiana shell (503925.00 $\pm 14.43 \mathrm{ppm})$. These results was in agreement with those expected by Zymantiene et al. (2006), Abd El-Aleem et al. (2015) and Etim (2015) who found that the damage depends not only on the activity and density, but also, on the feeding habits of snails and shells contained $48 \% \mathrm{CaCO}_{3}$.

\section{REFERENCES}

Abd El-Aal, E.M. and S.A. Hamed (2010). Controlling aspects against terrestrial snails eobania vermiculata and monacha cartusiana underlaboratory conditions. J. Agric. Res. Kafer El-Sheikh Univ., 36 (4): 463-479.

Abd El-Aal, S.M. (2001). Studies on certain land snails at Sharkia Governorate.” M. Sc. Thesis, Fac. Agric., Zagazig Univ., Egypt.

Abd El-Aleem, S.S.D., A.A. Sallam and T.M.M. Abd El-Rahman (2015). First record of two species from land snails, Monacha obstracta and Eobania vermiculata in Sohag 
Governorate, Egypt. J. Agric. and Food Sci., 3 (11): 206-210.

Abo-Elnaser, HAK. (2013). Ecological and Biological control studies on some terrestrial snails and their associated arthropods in Assiut Governorate. M.Sc. Thesis, Fac. Agric., Assiut Univ., Egypt.

Baker, G.H. and B.G. Hawke (1990). Life History and population dynamics of the bapisana (mollusca: helicidae), in a cereal pasture rotation. J. Appl. Ecol., 27:16-29.

Bezzerra, J.C.B., W. Becker and U. Ezelck (1997). A Comparative study of the organic acid content of the hemolymph of schistosoma mansoni - resistant and susceptible strains of biomphalaria glabrata. Inst. Oswaldo. Cruz, 92 (3): 421-426.

Bishara, S.I., M.S. Hassan and A.S. Kalliny (1968). Studies on some land snails injurious to agriculture in UAR Revue de Zoologieet de botaniqueafricainesLxx VII (3-4): 239252. Braz. J. Biol., 68 (4): 837-42.

Bislimi, K., A. Behluli, J. Halili, I. Mazreku, F. Osmni and F. Halili (2013). Comparative analysis of some biochemical parameters in hemolymph of garden snail (Helix pomatia L.) of the kastriot and ferizaj regions, Kosovo, 4 (6): 11-18.

Bowen, C.E. (1996). Conclusion-protein in aragonite shells of mullusc. Comp. Biochem. Physiol., 4: 269-275.

Bradford, M.M. (1976). A rapid and sensitive method for the quantitation of microgram quantities of proteins utilizing the principle of protein-dye binding. Anal. Biochem., 72: 248-254.

Crompton, M. and L.M. Birt (1967).Changes in the amounts of carbohydrates, phosphagen,and related compounds during the metamorphosis of the blowfly, lucilia cuprina. J. Insect. Physiol., 13: 1575-1595.

Dominika, M. (2008). Chemical composition and structure of the shell of cepaea vindobonensis (Férussac,1821) (Gastropoda : Pulmonata: Helicidae). 16 (1): 17-20.

Dubios, M., K.A. Gilles, J.K. Hamilton, P.A. Rebers and F. Smith (1956). Colorimetric method for determination of sugars and related substances. Analyt. Chem., 28: 350 356.

El-Deeb, H.I., Z.H. Zidan, M.M. Fouad and F.D. Asran (2003). Survey of terrestrial snails and their malacophagous insects at three governorates in Egypt. Egypt. J. Appl. Sci., 18: 355-361.

El-Gohary, L.R.A. and M.A.M. Genana (2011). Biochemical effect of three molluscicide baits against the two land snails monacha cantiana and eobania vermiculata.

El-Okda, M.K. (1981). Locomation activity and infestation abundance of certain terrestrial mollusca in fruit orchard, Alex. Province, ARE. Proc. $4^{\text {th }}$ Arab Pest. Conf., Tanta Univ., Egypt, 2 : 279 - 287.

El-Okda, M.K. (1984). Land mollusca infestation and chemical control in ElIsmaelia Governorate. Agric. Res. Rev., Egypt, 62: 87-92.

Eshra, E.H. (2013). Survey and distribution of terrestrial snails in fruit orchards and ornamental plants at Alexandria and ElBeheira Governorates, Egypt. Alex. Sci. Exch. J., 34: 242-248.

Etim, U.U.I. (2015). Mechanical and chemical properties of selected mullusc shells in Nigeria. Int. J. Agric. Policy and Res., 3 (1): 53-59.

Godan, D. (1983). Pest slugs and snails, biology and control. Springer-verlag Berlin, Heidelberg, 445.

Habig, W.H., M.J. Pabst and W.B. Jakoby (1974). Glutathione S-Transferase. The first enzymatic step in mercapturic acid formation. J. Biol. Chem., 249: 7130-39.

Ishaaya, I. (1971). observations on the phenoloxidase system in the armored scales aonidiella aurantiiand chrysomphalus aonidum. Comp. Biochem. Physiol., 39 : 935-943.

Ismail, S.A.A., S.A.A. El-Massry, M.M. Khattab and A.S. Hassan (2003). Daily activity and damage caused by eopania vermiculata (Muller.) (Gasttropoda: helicides) in citrus orchards. Egypt. J. Appl. Sci., 18 
(6B): 777-785.

Ismail, S.A.A., A.A. Rashed, F.M. Abou-Senna and M. Abed (2013). Physiological and histochemical studies on the land snail, monacha cartusiana in Sharkia Governorate. Egypt. J.Agric. Res., 91 (1): 207-216.

Ismail, S.A.A., S.Z. Shetaia and M.M. Khattab (2015). Time of application as main factor affecting the efficacy of certain pesticides against land snail monacha cartusiana under filed conditions at Sharkia Governorate. J. Pl. Prot. and Path., Mansoura Univ., 5 - 6.

Ittah, Y. and U. Zisman (1992). Evaluation of volatile allyl alcohol derivatives for control of snails on cut roses for export. Pest Sci., 35:183-186.

Knight, J.A., S. Anderson and J.M. Rawle (1972). Chemical basis of the sulfo-phosphovanillin reaction for estimating total serum lipids. Clin. Chem., 18: 199-202.

Lambert, L. (1973). Practical Chemistry. Heinemann Book Ltd. London, 54- 9.

Lokma, M.H.E. (2007). Studies on some terrestrial gastropods inguious to field crops at Sharkia Governorate. M.Sc. Thesis Fac. Agric. Zagazig Univ., Egypt.

Metwally, A.M., H.A. Zedan, A.B. El-Saeid and T.M.M. El-Akra (2002). Ecological studies on certain land snails in Monofia and Gharbia Governorate. Proc. of $2^{\text {nd }}$ Int. Conf., Pl. Prot. Res. Inst., Cairo, Egypt, 65-79.

Ohkawa, H., N. Ohishi and K. Yagi (1979). Assay for lipid peroxides in animal tissues by thiobrabituric acid reaction. Anal. Biochem., 95: 351 - 365.

Perkin-Elmer, C. (1964). Analytical Methods for Atomic Absorption Spectrophotometry. Norwalk, Conn.
Rady, G.H., A.A. Abdelgawad, S.H.A. Ismail and M.H. Lokma (2014). Ecology of some terresterial molluscs in Sharkia and Ismalia Governorates, 9 2(3): 907-920.

Ramzy, R.R. (2009). Biological and Ecological studies on land snails at Assiut, Egypt. M.Sc. Thesis, Fac. Sci., Assiut Univ., Egypt.

Reitman, S. and S. Frankel (1957). Colourimetric method for aspartate and alanine transaminases. Ame. J. Clin. Pathol., 28-56.

Shahawy, W.A., E. Hendawy, A.S.A. Abada and A.A. Kassem (2008). Land snails infesting rice plants and their accompanied parasitoids and predators at Kafr El-Sheikh Governorate, Egypt. Egypt. J. Agric. Res., 86: 971-982.

Shetaia, S.Z.S., S.A. Ismail and S.M. Abdel Kader (2009). Survey, population dynamics and importance value of certain land snail species infesting differed crops in Sharkia Governorate, Egypt. Acad. J. Biol. Sci., 1 (1): 37-43.

Snedecor, G.W. (1951). Statistical Methods Applied to Experiments in Agriculture and Biology. The Iawa State Coll. Press, $5^{\text {th }}$ Ed. Lawa USA.

Walsh, A. (1955). The application of atomic absorption spectra to chemical analysis. Spectrochim, 7: $108-117$.

Young, D.S. (1990). Effects of drugs on clinical laboratory edition, 3: 6-12.

Zymantiene, J., R. Zelvyte, C. Jukna, E. Jonaitis and A. Sederevicius (2006). Selected features of vineyard snails shell, their movement and physicochemical composition of foot meat. Biotechnol. and Biotechnol. Equip., 20 (1): 82-87. 
التمييز الكيميائى الحيوى لهيموليمف نوعين من القواقع (E.vermiculata and M.cartusiana)

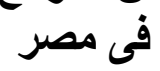

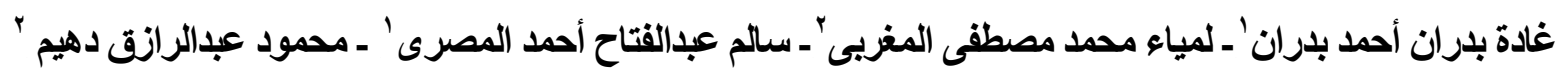

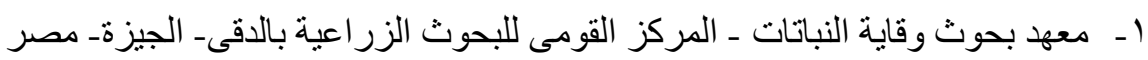



أُجريت هذه الدر اسة في محافظة الثرقية ـ مصر ـ لمقارنة محتوى المو اد الكيميائية الحيويه و النشاط الإنزيمى وتركيز

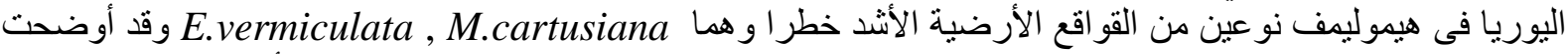



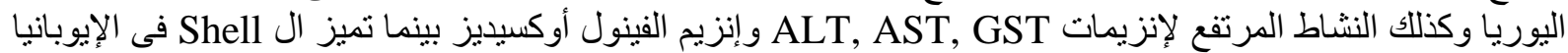

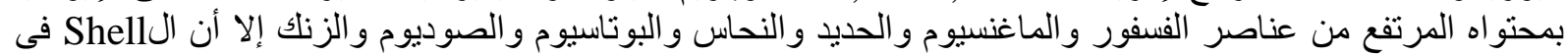

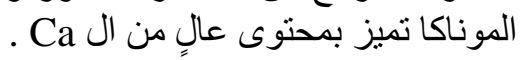

